\section{ENTRE LLANTOS Y LLAMAS: MÍSTICAS SUFÍES}

BETWEEN TEARS AND FLAMES: SUFI MYSTIC

María Teresa Arias Bautista Universidad Complutense de Madrid

Resumen:

Abstract:

El sufismo es una doctrina islámica que Sufism is an Islamic doctrine which consists in consiste en la búsqueda de una unión mística the search of a mystic union with Allah. This con Alá. Este estudio pretende explicar study aims to explain three points about the tres cuestiones acerca de la práctica de esta practice of this doctrine by women: their inner doctrina por parte de mujeres: su yo interior, self, their relationship with the environment su relación con el medio y su relación con and their relationship with God.

Dios.

\section{Palabras claves:}

Mística, sufismo, mujer.

\section{KEY WORD:}

Mystic, Sufism, woman.
Dado que no soy arabista me es imposible realizar una interpretación de los textos originales árabes para elaborar este estudio. No puedo, aunque bien quisiera, apasionarme por el simbolismo verbal y leer en profundidad las palabras árabes, a todas luces, llenas de significados. Tengo que conformarme con meditar sobre lo plenamente expresado en mi lenguaje, aunque, como enamorada de las palabras, pueda entender al ilustre metafísico, poeta y artista, Fritjof Schuon al afirmar que "la frase revelada es una alienación de símbolos cuyos detalles brotan a medida que el lector penetra en la geometría espiritual de las palabras" (Schuon, 1976: 64; cit. en Chador, 1999: 5).

Mi análisis, además, parte desde la diferencia de dos concepciones: la cristiana, en la que me he educado, y la musulmana, ajena a mí y sobre la que he tenido que realizar un esfuerzo de comprensión vertiendo, inevitablemente, mi forma de entender la vida. Ese ejercicio bascula, necesariamente, entre el Dios que triunfa en el Nuevo Testamento y otorga al ser humano libertad para seguirle o no, y el Dios musulmán autoexcluyente que mantiene sometidas a sus criaturas.

En el Islam nada puede hacer el ser humano para alterar aquello que está preestablecido desde el comienzo por la divinidad ${ }^{1}$. Nada puede hacer el hombre o la mujer que no sea querido por Dios². Todo viene de Dios, lo bueno y lo malo. El Dios musulmán interviene en las más mínimas cuestiones. Así, no sólo tolera, sino que estima convenientes y necesarias las desigualdades entre los seres humanos. Según sus designios cada quien ha de ocupar su lugar, el que le ha sido asignado, y ha de conformarse con él.

Desde el punto de vista espiritual el Dios musulmán exige al creyente la renuncia total y absoluta a todo lo que no sea Él, como indica Murata Sachiko: “Dios creó a los seres humanos para que lo sirvieran, fueran sus representantes en la tierra e hicieran su obra. Por eso Dios es el Señor y los seres humanos son sus servidores, los que aceptan libremente a Dios como su Señor" (Sachiko, 2001: 272).

El camino para acercarse a Dios en el Islam es seguir las enseñanzas reveladas en el Corán, así como los dichos y hechos del profeta transmitidos por los Haditz. El Corán nada tiene que ver con la Biblia, sino más bien con Jesucristo en la medida en que, como dice Flaquer, "Jesús es en el cristianismo la palabra de Dios hecha hombre y el Corán es la palabra de Dios revelada en el Libro" (Flaquer, 2004: 122).

\footnotetext{
1 "Tú no puedes adelantar un plazo fijado, ni rechazar lo que está determinado" (Ibn Arabi, 2007: $102)$.

2 “Este Dios Omnipresente, no deja apenas margen para la libertad humana. Si para toda religión es difícil compaginar la libertad del hombre con la Omnipotencia y Omnisciencia de Dios, en el Islam la balanza se decanta hacia el lado de Dios. Como Dios lo sabe todo, y como Dios lo puede todo, en el fondo nuestras vidas están trazadas de antemano. Estamos pues predestinados" (Flaquer, 2004: 121).
} 
El Libro Sagrado marca las pautas al o la creyente para conducirse por el recto camino hacia Dios. Sus palabras son luz para iluminar a los ignorantes: a los hombres y mujeres que están ciegos en este mundo. El Islam cree que todos los seres humanos han realizado un pacto con Dios antes de la creación, somos pues musulmanes, aunque hayamos olvidado este pacto pre-eterno (Flaquer, 2004: 121). Nada mejor que un texto de una mística sufí para entenderlo:

Vivía en Nubia, y mis padres eran cristianos. Un día mi madre me llevó a la iglesia y llevándome al pie de la cruz me pidió que la besara. Según me inclinaba para besar la cruz, vi una mano que me agarraba la cabeza y la giraba, con lo que mis labios no pudieron tocarla. Tiempo después entendí que el favor de Dios hacia mí es pre-eterno (Nurbakhsh, 1999: 96).

El Corán es, en palabras de Fatna Aít Sabbah:

Un intento por parte de Dios de ayudar al creyente a vencer las resistencias que su voluntad y sus deseos que amenazan con oponer al proyecto de amor-sumisión... El monopolio divino sobre todo lo que existe introduce un elemento que hace imposible cualquier noción de intercambio en la relación. De hecho, una de las partes figura entre las posesiones de la otra. El ser divino posee al creyente. La relación de posesión aniquila la posibilidad de intercambio... El ser poseído carece de voluntad... Este poder divino se encarna y manifiesta en el control total del tiempo y el espacio. El ser humano no tiene poder sobre su propia total del tiempo y el espacio. El ser humano no tiene poder sobre su propia existencia. Queda determinado, como privado de la capacidad de hacer Historia, su propia elaborado, incluidos los caminos que han de seguirse (Aít Sabbat, 2000: 127-129).

Para mí resulta evidente que las personas que creen en el Dios del Islam son conscientes de que, por mucho que se esfuercen, no llegarán nunca a alcanzar nada si Dios no lo quiere. Este Dios es inaccesible y no se muestra más que a quién Él estima otorgar dicha gracia. Las criaturas pueden hacer todo lo que esté en sus manos para acercarse a Él, pero no será suficiente si Él no lo juzga oportuno. Por eso podemos hallar muestras de frustraciones y ejemplos de hombres y mujeres que se pasaron su vida mortificando su cuerpo para alcanzar a Dios y Él se les escapa y muestra lejano ${ }^{3}$,

3 “Ibrâhîm Ibn Adham (príncipe de Balkh) iba en peregrinación a la Meca. Había tardado catorce años en atravesar el desierto, porque, a cada paso, hacía dos genuflexiones y oraba; por eso se decía tras tantos años pasados en la vía, se hallaba cerca de La Meca, descubrió aterrado que la Kaaba no estaba en su lugar. Dijo entonces llorando: ¡¡Ay de mí! ¿Qué ha sucedido? ¿Me habré quedado ciego, pues no puedo ver su imagen luminosa? Entonces escuchó una voz, que le decía. -Oh Ibrâhîm, no estás ciego. La Kaaba no está aquí ha ido al encuentro de una mujer que viene de camino. Ibrâhîm quedó conmocionado y gritó - ¿Quién es ella? Salió corriendo y vio a Râbe'ah, que se acercaba apoyada en un bastón; vio también que la Kaaba volvía a su lugar. Con lágrimas de resentimiento en los ojos dijo: -jOh Râbe'ah! ¿Qué has hecho? ¿A qué tanto trastorno? Conmocionas al mundo, todos hablan de ti, y las gentes de Dios dicen: La Kaaba ha ido al encuentro de Râbe'ah... La casa de Dios prefirió ir a tu encuentro" (Râbe'ah Al-'Adawiyya, 2006: 65-66). por el contrario, se manifiesta en niños que aún no han realizado méritos para alcanzar tales dones ${ }^{4}$.

Estas premisas me inclinan a entrever que aunque la mística cristiana y la mística del Islam tienen en común la renuncia a la vida material, al propio cuerpo, a la propia identidad y a la voluntad de ser; y que incluso poseen formas de expresión comunes referidas a la unión con Dios, sus puntos de partida son diferentes. El alma cristiana puede acercarse a Dios con su esfuerzo, con su ascetismo, con la práctica de la bondad. La fe y la fuerza residen en ella porque Jesucristo posibilitó el nexo roto entre Dios y el ser humano. Dios está dispuesto a recibirla, más que por el hecho de que supere su miseria, transitando por los páramos de la soledad y el sacrificio, por la obra salvífica del Redentor.

Estas sucintas apreciaciones personales sobre las diferencias entre dos puntos de acercamiento a lo divino, tienen, sin embargo, bastantes similitudes en la actitud de las dos religiones y, en consecuencia, de las dos sociedades, en lo referente a las mujeres. Por lo menos si comparamos etapas similares en el tiempo en que se desarrolla el sufismo que vamos a analizar; es decir, la Edad Media. Ambas hicieron de la sumisión femenina la base sobre la que se asentaban.

Para el estudio que nos ocupa me he centrado en la obra del doctor en psiquiatría y profesor en la Universidad de Teherán, Javad Nurbakhsh, Maestro de la Orden Sufí Shah Nematollah Wali, fallecido hace un año. Dicha obra, aparecida en 1999, lleva por título "Mujeres sufíes" y en ella, el autor recopiló las escuetas biografías, a veces sólo leves trazos de existencia, de 136 mujeres.

Intentar hallar en ellas un denominador común que no sea su necesidad de acercarse a Dios, su espiritualidad, es tarea vana. Lo que las une es el llanto por la lejanía de Dios y las llamas en que se abrasa su alma con el encuentro divino. Lo que las caracteriza, desde el punto de vista terreno, es pues la diversidad. Las hubo solteras, casadas y viudas. Jóvenes, viejas e incluso bebés, si nos atenemos a algunos relatos. Las hubo ricas y pobres, vagabundas y mendigas, libres y esclavas. Supervivientes gracias a los manjares enviados por la divinidad o trabajadoras dedicadas a diferentes oficios con los que se pagaban su sustento. Con filiación conocida o desconocida, incluso de algunas ni siquiera se conoce el nombre. Ascetas y místicas, hacedoras de milagros,

4 "Le conocí en la mezquita de 'Udays, en Sevilla, cuando todavía no tenía diez años. Este chico triste y meditabundo tenía éxtasis y estupores intensos. Poco antes de conocerle, había recibido una apertura intuitiva a este camino, y nadie lo sabía..." (Ibn Arabi, 2007: 131).

"Su hija que no tenía un año estaba tan influida por su estado espiritual que, cuando los hermanos se reunían para el dhikr, formando un gran círculo, ella saltaba de las rodillas de su madre y venía a ponerse de pie en medio del círculo. En aquellos momentos, el éxtasis la subyugaba. Incluso a una edad tan temprana, mostraba con su actitud que Alá había colocado en su corazón una luz que le comunicaba un conocimiento espiritual. Murió antes de haber sido destetada" (Ibn Arabi, 2007: 131). 
cultas e ignorantes, reconocidas como santas y sabias o tenidas por locas. Alejadas de la comunidad o insertas en ella, con discípulos o sin ellos...

Me centraré en tres cuestiones principales: la que atañe a sí mismas, a su relación con el medio y a su relación con Dios. Tres cuestiones que, en realidad, se hallan íntimamente unidas y a través de las cuales podemos observar como emergen sus peculiaridades con respecto al resto de las mujeres y su comportamiento fijado por el Libro y la costumbre. Normas insertas en un contexto patriarcal que a todas subyugaba y minusvaloraba.

Las mujeres sufíes saltaron la desigualdad impuesta y fueron consideradas hombres, como fórmula para manifestar que habían superado la identidad asignada y se habían apropiado de otra que, al menos teóricamente, no les correspondía.

\section{Mujeres en el Islam y mujeres sufíes}

\subsection{Rescate de las mujeres}

Desde hace relativamente poco se observa un intento de rescatar a las mujeres que tuvieron un eco en la Historia del Islam. Quizás no tanto por mimetismo de la búsqueda de la genealogía femenina en Occidente, como por responder a nuestro discurso sobre la inexistencia de mujeres destacadas debido a la sofocación a que han estado sometidas.

Al hilo de este movimiento, han surgido obras que ponen a disposición de los lectores vidas y hechos de mujeres singulares que compartieron poder por sus enlaces matrimoniales o por circunstancias determinadas. Y lo hicieron incluso en la guerra aunque fuera en labores auxiliares y de cuidado.

Sin embargo, si leemos estas obras atentamente descubriremos que las mujeres a que se refieren detentaron un poder delegado o ejecutado por imperiosa necesidad que acabará siendo engullido por el sistema. Textos como los que recoge López Pita muestran aquello a lo que me estoy refiriendo, porque, aunque las acciones femeninas sean precisas, equilibradas y destacables, el principal problema es que provenían de una mujer: "Sus acciones fueron examinadas estrictamente sin que se encontrara en ella ningún fallo, excepto que era mujer" (Ibn Arabi, 2007: 107). O este otro: "Radiya, aunque era mujer, tenía la cabeza y el corazón de un hombre y era mejor que veinte de sus hijos" (Ibn Arabi, 2007: 106).

Las fuentes en que beben estos trabajos son las de antiguos oradores y escritores musulmanes que dedicaron atención a las mujeres. López Pita nos habla de que incluso se creó un género específico dedicado a las mujeres llamado “Noticias de mujer". Ibn
Sa'ad, por ejemplo, consagró el último volumen de su obra enteramente a las mujeres, lo mismo que ocurre en los textos de Tabari donde aparece la historia de los seguidores del profeta y de mujeres que participaron activamente en los primeros momentos para imponer el Islam (Mernissi, El poder olvidado: 163, 166, 177; Mernissi, 2004: 336)

\subsection{El sufismo y el rescate de las mujeres sufíes}

Anidado en el corazón del Islam, el Sufismo nace en él, bebe de sus fuentes y no puede ser entendido fuera de él ${ }^{5}$. Esta es la máxima que nunca debe olvidarse al intentar su estudio que se muestra como un tema complejo desde el primer momento. Especialmente, porque el sufismo no se encierra en fórmulas y se sustrae sutilmente al análisis, debido a las cualidades especiales de su significado. El sufismo no es una secta, ni constituye una teoría, tampoco posee un cuerpo doctrinal que lo organice, es más bien una forma de vida catapultada al infinito. Para Bárcena: “Es una realidad inefable, indefinible, no divisible, que sólo admite ser vivible... deja de serlo cuando es descrito. El sufismo que se puede nombrar, no es sufismo. Hablar sobre él es, en cierto modo, traicionarlo" (Bárcena, en internet).

Podemos decir que existe una gran dificultad para hacer comprensible mediante las palabras, algo tan etéreo y subjetivo como la experiencia mística ${ }^{6}$, ya que ésta,

\footnotetext{
5 Para Brukhardt el sufismo es la quinta esencia de las enseñanzas del profeta. Tanto para él como para otros autores como Masignon, Chevalier y Nasr, la fuente exclusiva del Sufismo se encuentra en la doctrina islámica. Otros opinan que aunque las raices sean islámicas, el sufismo recogio tendencias ideológicas y religiosas, a lo largo de su historia, que se hallaban en el ambiente, segun se ponían en contacto con los diferentes pueblos a los que iba sometiendo. La conexion entre la mistica cristiana y sufí ha sido estudiada por numerosos investigadores, especialmente, en lo tocante a los préstamos simbólicos en torno a la unión mística. San Juan de la Cruz, Santa Teresa, e incluso la condenada po hereje, Margarita Porete, han declamado una forma de union que enlaza con los sentimientos místicos sufíes, como Ibn Arabi, Hallaf o Râbe'ah, entre otros. En palabras de María Tersa Cuadra podemo decir que: "al leerlos notamos una especie de denominador comun, unas invisibles similitudes que trascienden más allá de las palabras. Algo así como si formaran un todo, sin tiempo y sin raza, un eco de almas privilegiadas que por una gracia especial han llegado a conectar con la ternura divina... Algo así como un gemelismo espiritual. Cada cual con su formación y desarrollo ideológico individual pero con una misma obsesión, un mismo ideal, una misma meta: el conocimiento y la unión con Dios" (Cuadra, 1977).

6 La mística se engrana en la espiritualidad humana, que según Pareja "es la propiedad del alma contrapuesta a la materialidad" (Pareja, 1969: 78). La espiritualidad puede tomarse en dos sentidos: uno filosófico o psicológico, y el otro el que se da en la ascética y la mística, cuando con estas palabras se habla de la perfección del ser humano en orden a la consecución del último fin. Mística es, en general, todo ideal por el que se ha consagrado la vida, y ello afecta a las ideologías. La mística religiosa puede ser natural o sobrenatural. La primera es un tipo de relación con el absoluto, al que se llega partiendo de una vida espiritual intensa y de ejercicios ascéticos, y no por el conocimiento discursivo, sino por el intuitivo, el cual se da en el fondo del alma. Pero nada nos dice que este absoluto sea Dios; puede ser el encuentro con uno mismo, como sucede con el yoga hindú o la contemplación filosófica de Platón y Plotino. La mística sobrenatural es el desarrollo de la vida de la gracia en el hombre, que tras una fase de purificación activa y pasiva, hace renacer en el alma los dones del Espíritu, de tal forma que el alma se une con Dios. De una manera más sencilla definiremos la mística como "una expresión constante de la universal aspiración del alma humana hacia la comunicación personal con Dios" (Arberry, 1952: 8).
} 
es esencialmente personal y no puede ser interpretada más que a la luz de la vida del místico que va más allá de cualquier expresión verbal, generalmente cargada de subjetividades. La mente, en palabras de Burckhadt, "no encuentra palabras para expresar la vivencia, sólo puede aproximarse a ella rozándola levemente, con el fin de hacerla inteligible para el resto de los humanos que carecen de la experiencia" ${ }^{7}$.

La mística del Islam se conoce con el término Ta Sawwuf ${ }^{8}$ y los místicos se denominan a sí mismos Ahl Al-Tasawwuf. Para su comprensión se han propuesto numerosísimas etimologías. A comienzos del siglo II/VIII, comenzó a usarse la voz Sûfî, aplicada a los místicos; término para el existen igualmente demasiadas interpretaciones ${ }^{9}$. Independientemente de todas ellas, pronto se generalizó y adquirió un sentido simbólico que designó a quienes buscaban a Dios por medio del despojo interior ${ }^{10}$.

El empeño de toda persona que se entregó a la búsqueda de la Verdad divina en el Islam, al conocimiento de $\operatorname{Dios}^{11}$, ya fuera en solitario, o a través de una Tariqa o cofradía; Podemos decir que una espiritualidad especial impregna el alma de unos pocos dentro de cada
religión. Ella les lleva a la búsqueda de un conocimiento superior y a la unión con Dios. Esta búsqueda se conoce como mística en todas las religiones.

7 La mayoría de los investigadores, y por citar a algunos de ellos hablaremos de Chevalier Massignon, Caspar, Arberry, Lings, Pareja..., entienden el sufismo como la mística islámica, aunque utilice diferentes fórmulas para definirlo. No la hace, sin embargo, Burckhart, quien admitiría dich significado si se entendiese éste "en el sentido en que lo empleaban los Padres Griegos, es decir, para designar lo que tiene relación con el conocimiento de los misterios". Para este autor, "el sufismo es el
esoterismo islámico" (Burckhardt, 1980: 23).

8 Pueden hallarse, no obstante, voces, como la de Halil Bárcena, que se muestran disconformes con esa afirmación, puesto que aseguran que "hay vias misticas islámicas no sufies, como es el caso de la si'a ismấ̂̂lî". Para estos pensadores, "el sufismo es más un camino de conciliación del amor y el conocimiento que una doctrina o sistema filosófico" (Bárcena, en internet).

9 Para algunos, por ejemplo deriva del griego "sofos", sabio, y "sofia", sabiduría, lo que Chevalier ha negado pues "no es así ni desde el punto de vista filológico, ni semántico" (Chevalier, 1974: 303).

También se ha hecho derivar de Sûf (lana) por la vestidura de lana no teñida que llevaban los sufíes, atuendo que se generalizó a partir del siglo III/IX, aunque no todos lo llevaron. Se le ha hecho derivar de ahl al-suffah (los del sitial, sofá), que designa a un grupo de compañeros del Profeta que solían parar en una banca a las afueras de la Mezquita de Medina, así como de safá (purificarse, clarificarse) pues de eso se trata de purificarse (Bize).

10 Sufiya, como apelativo colectivo para los místicos, apareció por primera vez en Alejandría, allá por el año 199 de la Hégira, para denominar a un grupo de puritanos insurrectos que clamaban contra el abandono del espíritu islámico. Medio siglo más tarde se aplicó de un modo más restrictivo a un grupo de ascetas de Kufa. Finalmente, tras la toma del poder por los Abbasies, el vocablo se aplicó a la corporación de los "místicos de Bagdad" y, posteriormente, sirvió para denominar a todos los místicos del Irak.

11 El conocimiento de Dios puede ser de dos tipos: intelectual o cognoscitivo y emocional o afectivo Para entender esta diferencia bastará con observar las distintas posiciones de los sufíes. Una actitud fundamentalmente intelectual es la de Ibn-'Arabi, quien como otros consideran la realidad divina como la esencia universal de todo conocimiento. Otros como Hallag se expresan en el lenguaje del amor, y para ellos la realidad divina es ante todo el objeto ilimitado de su deseo. ya fuera aislada o integrada en la comunidad, se realizaba mediante verdaderos esfuerzos ascéticos por medio de la oración, la vigilia, el ayuno, el castigo corporal, el alejamiento del mundo, la pobreza... Con ello pretendía, como dice Burckhardt, "mantener el alma abierta al influjo del infinito" (Burkhardt, 1980: 48), y prepararla para los estados místicos, que ya no dependen del hombre sino de Dios.

Para conseguir la unión mística del alma con Dios, el sufí ha de conocerse a sí mismo y purificarse de todo lo reprobable, por medio de la ascesis, camino que se divide en etapas o estaciones, méritos, que conducirán a las siguientes etapas místicas, que son dones (Arberry, 1952; 87). En una palabra, la vía es pues ascético-mística y según el estadio en que se encuentre el místico que lo recorre será murid (principiante), salik (proficiente) o kamil (perfecto). En la vía se va adelantando por grados, sin pasar a una superior hasta no haber recorrido las anteriores. El número de etapas varía mucho según los autores, ya que cada uno se funda en su propia experiencia ${ }^{12}$.

El método para llegar a la perfecta unión, parte de las normas que ha de cumplir todo buen musulmán pero no sólo cumpliendo los ritos exotéricos, sino que dentro de las cinco normas básicas hay una interpretación y cumplimiento esotérico que es el que llevan a cabo los sufíes. Así el Salat (oración o recitación de la palabra divina contenida en el Corán) se convierte, a medida que se avanza por el camino espiritual en "oración del corazón". Cualquier recitación repetida de una fórmula o frase sagrada en voz alta o interiormente se designa con el nombre genérico de dikr, que significa al mismo tiempo, mención, evocación, remembranza y recuerdo. El dikr es en el sufismo el medio central de su método (Burkhardt, 1980: 122). Esta recitación se cumplimenta con un ritmo prefijado, en voz alta o baja, sincronizado con los movimientos de la respiración y con diferentes posiciones del cuerpo. Algunos lo acompañan con actos de penitencia como flagelación. También puede ser acompañado con todo el cuerpo, en esto consiste el principio de la danza sagrada practicada por algunas comunidades sufíes, conocida como sama. Otro método de oración es el Fikr, meditación discursiva, completamente indispensable en el rito.

La Sahada, profesión de fe, es la fórmula más utilizada en el dikr. En algunas ordenes sufies la primera parte "No hay más Dios que Alá" ha de ser recitada por el neófito centenares de miles de veces, con el fin de hacerla brotar desde un punto profundo de la conciencia (Lings, 1981: 78). La segunda parte de la profesión que testimonia que Mahoma es el mensajero de Dios, es para el “viajero" el resumen del camino espiritual.

12 El conocimiento de Dios puede ser de dos tipos: intelectual o cognoscitivo y emocional o afectivo. Para entender esta diferencia bastará con observar las distintas posiciones de los sufíes. Una actitud fundamentalmente intelectual es la de Ibn-'Arabi, quien como otros consideran la realidad divina como la esencia universal de todo conocimiento. Otros como Hallag se expresan en el lenguaje del amor, y para ellos la realidad divina es ante todo el objeto ilimitado de su deseo. 
En cuanto al Zaqat o limosna, no es para el sufí solamente la "purificación de los bienes propios" mediante el acto de caridad que ayuda al pobre, sino también el "don de sí" y la comprensión de la verdad de que en virtud del origen divino de todas las cosas, y no por una forma cualquiera de humanitarismo, el otro, soy yo mismo.

El ayuno, no significa únicamente la abstención de comida, bebida y pasiones mientras dura la luz en el mes de Ramadán sino, por encima de todo, la comprensión de la independencia fundamental del ser del hombre con respecto al mundo externo y su dependencia de la realidad espiritual que reside dentro de él.

La peregrinación a la Meca es exteriormente el viaje hacia la casa de Dios e interiormente la peregrinación al interior del corazón, que también es la casa de Dios.

En cuanto a la Guerra Santa no significa sólo la defensa y expansión del Islam, sino la constante guerra interior frente a todo lo que impide al hombre ver la verdad y la lucha contra el desequilibrio interior.

A través de la práctica continuada de todas estas virtudes, los sufíes llegarán al "estado unitivo", ellos son los ahl-i qurb, es decir, los que gozan de la proximidad de Alá y en ella se complacen. Hay tres grados: los que se esfuerzan en avecinarse con Él, los que están más cerca de Alá que de cualquier otra cosa y los que están abismados en Alá y no se percatan de su estado (Nicholson, 1986: 51).

Todo el sufismo descansa en la creencia de que cuando se pierde uno a sí mismo se encuentra en el Yo Universal, o dicho en lenguaje religioso, en el éxtasis se produce solo y exclusivamente la forma de comunicación directa entre el hombre y Dios. La absorción en el éxtasis constituye el fin de la peregrinación para los sufíes. En lo sucesivo, como indica Pareja, cesa toda relación entre ellos y el mundo. Nada de ellos queda en ellos porque han muerto como individuos sumergidos en la unidad, no conocen ya ni ley $\mathrm{ni}$ religión, ni forma alguna de ser contingente (Pareja, 1969: 143).

Para finalizar podemos decir que los sufíes siempre se han considerado a sí mismos como elegidos de Dios y que este movimiento de trascendencia vivificó el Islam, y lo sacudió profundamente dándole nuevas perspectivas y esperanzas. En especial porque la visión de un Dios de amor es más reconfortante y gratificante para el hombre que espera el perdón que un Dios del terror y del juicio. El Sufismo, además hizo estallar el lenguaje corriente al dar nuevos contenidos a las palabras, nuevas dimensiones necesarias para expresar tan maravillosa experiencia.

De entre las mujeres que más huella han dejado en el mundo musulmán se encuentran las mujeres sufíes. Y ello porque la interpretación del Corán al modo que lo hacían los sufíes posibilitaba el reconocimiento de las mujeres como seres capaces de alcanzar la santidad y la sabiduría.
María Tabuyo recoge las obras en que se ha hecho alusión a las mujeres sufíes. Mujeres que han llegado hasta nosotros no a través de ellas mismas, pues el cálamo no ha sido, precisamente, atributo femenino, sino a través de la tradición oral en la que han bebido, posteriormente, los autores masculinos que han creído oportuno hacer acopio de sus vidas y obras. Esta recuperación es un importante patrimonio para todas las mujeres y en especial para las mujeres musulmanas pues, en la negación de su existencia, o en la ignorancia de la misma, se asientan las falsas verdades de la ausencia de capacidades femeninas fuera de las fórmulas tradicionales que se les han encomendado.

Según María Tabuyo, Ibn Sa'd incluye retratos de numerosas mujeres sufíes. AlMurawi homenajea a 35 de ellas y Jawzî lo hace con 240. Éste último aunque no era muy amante del género femenino critica a Al-Is-Jathâmî por ignorarlas. El comentario de este autor es bastante elocuente al entregarnos una verdad incuestionable: "No mencionar a las mujeres, hace que los hombres ignoren a las mujeres en general" (Tabuyo, 2006: 21)

Una verdad que el feminismo proclamó de forma similar con la frase "lo que no se nombra no existe" para referirse al olvido en el que la Historia colectiva había mantenido a las mujeres. Esta búsqueda de mujeres santas, probablemente, ha tenido que ver con la aparición, en 1991, en Arabia Saudi, de una obra que se pensaba perdida y que hace alusión a 84 mujeres sufíes.

La obra de Javad, sobre la que he realizado mi estudio cita, como ya he indicado, a 136 mujeres sufíes y nos lleva de Rabếah al-Adawiyya, la más conocida, que vivió a principios del siglo VIII, hasta Bibi Hayâti Kermâni, poetisa y mística del siglo XIX. Siendo, la inmensa mayoría mujeres de la etapa medieval.

2.3. Mujeres y mujeres sufíes: ¿Iguales o diferentes a los varones?

Según afirman los teóricos del Islam, "en términos de fe: hombres y mujeres son iguales" (Nurkbakhsh, 1999: 18) y remiten para ello tanto al Corán como a los Haditzes. Así la afirmación: "Dios no se fija en vuestras formas", habría de ser interpretado, según Javad Nurbakhsh como "en la senda del ascenso a la Verdad, la obra del corazón es la que se mide y no la forma corporal de carne y hueso" (Nurkbakhsh, 1999: 18-19).

No es momento de discutir esta afirmación sinuosa que manifiesta dos posibilidades de ser y de estar, la de ser carne o ser espíritu; la de ser mujer o ser varón. Dos posibilidades que enajenan a quienes se sitúan exclusivamente en el mundo y premian a quienes superan su realidad terrena. Dos posibilidades que hacen de la mujer naturaleza, impureza y debilidad y del varón espíritu, pureza y fuerza. Ya el Profeta marcó las diferencias en Aqaba: 
Durante la noche en que se acordó el compromiso de Aqaba, los hombres estrecharon la mano del Profeta... Umm Mani y yo permanecimos allí. Entonces mi marido, 'Arafa ibn 'Amr dijo en voz alta: mensajero de Allah, estas dos mujeres están aquí con nosotros para jurarte lealtad. A lo que el profeta respondió: Acepto manera que la acepté de ti, pero no estrecho la mano de las mujeres (López Pita, 2002: 96).

La explicación es sencilla. No podía saberse si una mujer estaba en período de menstruación durante el cual se la consideraba impura: "Aicha ha dicho: Nunca la mano del Enviado de Alá tocó la mano de una mujer, salvo que ésta le perteneciera" (El Bokhari, 1964: 39-49).

Impureza, pertenencia... Son palabras que hablan de una realidad que condiciona la libertad y la trascendencia. Tampoco voy a discutir otras ideas que se articulan en torno a la mejora que para las mujeres supuso históricamente la aparición de la nueva religión en Arabia debido al trato inhumano que padecían. O aquella otra que asegura que en los primeros tiempos de la imposición de la fe musulmana las mujeres estuvieron equiparadas a los varones y destacaron en los diversos conocimientos y el ejercicio del poder. Todo ello pudo ser cierto pero, lo que podemos constatar es que, superados dichos primeros tiempos, la mujer devino un ser carente de derechos y se redujo a una carne poseída, desheredada de sí y de todo poder, subordinada a los varones y con muchas servidumbres negativas en su haber. Las mujeres, por el hecho de serlo, y debido a la carga simbólica que se hizo recaer sobre ellas, debían ser veladas y encerradas.

Por ello, independientemente de que en los primeros tiempos del Islam muchas mujeres fueran rescatadas de su muerte por la práctica brutal del infanticidio femenino, o que hubiese mujeres que destacaron en todos los campos, lamentablemente, sus cualidades y calidades no dejaron suficiente huella porque el género femenino terminó siendo engullido por el sistema que establecía unas clarísimas pautas de comportamiento para hombres y mujeres. La igualdad no era real, en tanto en cuanto el varón es superior a la mujer y así puede leerse tanto en el Corán como en los Haditzes:

\section{[...] Ellas tienen derechos equivalentes a sus obligaciones, conforme al uso, pero los hombres están un grado por encima de ellas (C. II, 228).}

Que la posición del varón equivalga a la de dos hembras (C. IV, 11).

Los hombres tienen autoridad sobre las mujeres en virtud de la preferencia que Dios ha dado a unos sobre otros y de los bienes que gastan. Las mujeres virtuosas son devotas y cuidan, en ausencia de sus maridos, de lo que Dios manda que cuiden. ¡Amonestad a aquellas de quienes temáis que se rebelen, dejadlas solas en el lecho, pegadles! Si os obedecen no os metáis más con ellas (C. IV, 34). La mujer que muere y su marido está satisfecho de ella, va al Paraíso (Ghazzali, 1989: 105). Vi un día el Fuego y la mayoría de sus habitantes eran mujeres; vi el Paraíso y la menor parte de sus habitantes eran mujeres (Ghazzali, 1989: 105).

Refirió Abu Said Al-Khudri: Una vez el Apóstol de Alá salió a la Musalla (a realizar la oración) de ‘Id-al-Adha o al-Fitr. Pasó junto a las mujeres y dijo: “¡Oh mujeres! Haced limosnas, que he visto que la mayoría de los habitantes del infierno erais vosotras". Preguntaron: “¿Por qué es así, oh Apóstol de Alá?” Contestó: “Maldecís frecuentemente y sois ingratas con vuestros maridos. No he visto a nadie más deficiente en inteligencia y religión que a vosotras. Un hombre precavido y sensato podría ser extraviado por algunas de vosotras”. Las mujeres preguntaron: “¡Oh Apóstol de Alá! ¿Qué es deficiente en nuestra inteligencia y religión?” Dijo: “¿No es el testimonio de dos mujeres igual al de un hombre?" Lo confirmaron. Dijo: “Esto es la deficiencia en su inteligencia. ¿No es verdad que una mujer no puede rezar ni ayunar durante sus periodos?" Las mujeres dijeron que sí. Dijo: “Esto es la deficiencia en su religión (Bukhari).

Si tuviese que ordenar a una persona que se prosternara ante alguien que no fuera Dios, seguramente hubiera ordenado a la mujer que se prosternara ante su marido. Por Aquél que detenta en sus manos el alma de Muhámmad, proclamo que la mujer no cumple su deber ante Dios si antes no ha cumplido su deber con su marido (Tirmidhi y Zafrulla Khan, 1989: 69). Toda mujer que se sustrae a pernoctar con su marido, los ángeles la maldicen hasta el amanecer (Ascha, Du statut inférieur: 97-103, cit. en Torres Calzada, 2008: 81-82)

Estas breves líneas muestran con claridad la sumisión y la obligación de la mujer a satisfacer al esposo, so pena de incurrir en la ira de Dios y en la del marido que tiene absoluto derecho a corregirla, reprenderla y castigarla. Como señala Katjia Torres:

\section{Laconfiscacióndelcuerpofemeninoeselmecanismoqueimpideafirmarlaautonomía asumir la propiedad de la mujer misma, dejar de ser el reflejo de la mirada del otro e imposibilita la vivencia de su propio cuerpo. La mujer debe aprender a hacerse cargo de su esquema corporal y trabajar las tres dimensiones del cuerpo, esquema imagen y experiencia: sexualidad, conciencia y salud. La mirada femenina y los ojos de las mujeres están envueltos en tabúes y tópicos" (Torres Calzada, 2008: 90).}

Efectivamente, las mujeres estaban condenadas a no mostrarse como criaturas libres y los tabúes en torno a su biología hacían más difícil superar su corporeidad: las menstruantes no pueden aún, como nos indica Nurbakhsh recitar oraciones, leer el Corán, entrar en la mezquita, etc. (Nurbakhsh, 1999: 31). La menstruación es un mal del que hay que apartarse: 
Te preguntan acerca de la menstruación. Di: «Es un mal. ¡Manteneos, pues, aparte de las mujeres durante la menstruación y no os acerquéis a ellas hasta que se hayan purificado! Y cuando se hayan purificado, id a ellas como Alá os ha ordenado». Alà ama a quienes se arrepienten. Y ama a quienes se purifican (C. II, 222).

Podríamos hallar similitudes doctrinales en el mundo cristiano medieval pero, la mayoría de ellas, han sido ya superadas.

Por otro lado, una cuestión nada baladí sería la de la promesa del más allá, que se comprueba absolutamente diferente para mujeres y hombres. Existe, como indica Ait Sabbah:

Un mutismo general sobre cómo estarán las mujeres en el Paraíso, mientras que si se describe perfectamente como lo haran ellos. Los varones que parecen ser recibidos con todos los parabienes y privilegios, recibirán como premio a mujeres perfectas siempre jovenes, virgenes, para ¿Dónde está pues la igualdad entre hombres y mujeres? (Aít Sabbath, 2000: 140).

Y les daremos por esposas a huríes de grandes ojos (XLIV, 51-55).

Nosotros las hemos creado de manera especial y hecho vírgenes, afectuosas, de una misma edad, para los de la derecha (LVI, 12-38)

Podría decirse que existe una gran desventaja entre ser mujer o ser varón en cuanto a la recompensa, pues aunque el Corán indica:

Al creyente, varón o hembra, que obre bien, lo haremos ciertamente, que viva una vida buena y le retribuiremos, si, con arreglo a sus obras (XVI, 97). El creyente varón o hembra, que obre bien, entrará en el Jardín y no será tratado injustamente en lo más mínimo (IV, 124).

\section{La autora citada subraya:}

En ningún lugar se toma en consideración las necesidades de las mujeres terrenales. Es sorprendente la indiferencia con las necesidades sexuales de la mujer, que contrasta con la extrema minuciosidad con que se programa la satisfacción orgásmica del hombre... la armonización de los placeres y su multiplicidad aseguran la total satisfacción del creyente del sexo masculino, que parece ser el único huésped que importa de hecho (Aít Sabbath, 2000: 140-141).

En el Islam, tanto el Corán como la Sunna, prescriben el matrimonio como el más apropiado y casi obligatorio para el y la creyente (Torres Calzada, 2008: 79), mientras que el celibato no es bien comprendido. El contrato sexual establecido se perfila con grandes ventajas para el varón, en relación con la mujer, toda vez que es libre de elegir cuantas mujeres desee a través de dos instituciones fundamentales: la poligamia y el repudio.

Todas las cuestiones enunciadas hablan de una limitación impuesta al desarrollo intelectivo de las mujeres musulmanas. Sometidas a las obligaciones de la maternidad y el cuidado debieron vivir para los demás y renunciar a otras posibles expectativas, situación que hacía perder a la sociedad un patrimonio capaz de enriquecerla, como tuvo la valentía de observar el filósofo cordobés Averroes:

Nuestro estado social no deja ver lo que de sí pueden dar las mujeres. Parecen destinadas exclusivamente a dar a luz y amamantar a los hijos, y ese estado de servidumbre ha destruido en ellas la facultad de las grandes cosas. He aquí por qué no se ve entre nosotros mujer alguna dotada de virtudes morales: su vida qué no se ve entre nosotros mujer alguna dotada de virtudes morales: su vida
transcurre como la de las plantas, al cuidado de sus propios maridos. De aquí transcurre como la de las plantas, al cuidado de sus propios maridos. De aquí
proviene la miseria que devora nuestras ciudades porque el número de mujeres es doble que el de hombres (Averrores, Tomo 1: 348; cit. en Martín,1980: 78).

Este ha sido y aún continúa siendo el panorama general para el común de las mujeres musulmanas. Me acercará ahora a la teórica consideración de igualdad de que han gozado las mujeres sufíes. Será preciso considerar qué pensaban los hombres y, especialmente, sus compañeros sufíes, toda vez que para los varones el camino era practicable por cuantos deseasen emprenderlo. Sobre esta consideración de género la profesora de religiones, Sachiko Murata afirma que:

\begin{abstract}
Si preguntásemos a Râbe'ah o a cualquier otro sufí sobre las mujeres de luz, nos dirían que no nos preocupásemos tanto acerca del cuerpo que nos mantiene encadenados a nuestros prejuicios sobre la sociedad y la psicología y nuestros conceptos de justicia e igualdad. Nos diría que si queremos entender a las mujeres y a los hombres tenemos que pedirle a Dios que nos permita reconocernos a nosotros mismos y a nuestro Señor... Para el contexto islámico las mujeres de luz son las mujeres que Dios ha transformado en luces. Y la luz de la mujer es la luz de Dios, que es, según el Corán la luz de los cielos y de la tierra. Pero luz de las mujeres quejién es la luz de los varones. Las mujeres no tienen un acceso especia a la luz to especial a la luz y tampoco los varones. El acceso especial a la luz se les da a los seres humanos y las distinciones de género no desempeñan ningún papel en la esencia de nuestra humanidad, la esencia que está abierta a la luz. No creo que a Râbe'ah y a los otros santos del Islam les preocupase en absoluto los papeles de género impuestos sobre ellos por las convenciones sociales y religiosas. No les interesaría ni la feminidad ni la masculinidad en la sociedad porque el conocimiento de esas cosas carece de utilidad permanente en nosotros. Carece de utilidad porque es conocimiento de cuerpo, no conocimiento de la religión (Murata, 2001: 270-271).
\end{abstract}

Este discurso ya lo anticipó el poeta sufí 'Attar quien afirmó de Râbe'ah de Basora: "Ella no era sólo una mujer, sino igual a cien hombres... libre de cualquier contingencia superflua, inmersa en la Verdad" (Nurbakhsh, 1999: 21). Por eso, aún admitiendo la 
aseveración de Murata, en lo relativo a la indiferencia de quien ha llegado al final del camino por los conceptos que afectan a nuestra humanidad sexuada, postura que también defienden otros autores como Javad Nurbakhsh cuando dice: “Desde el punto de vista de los sufíes, las mujeres que han avanzado firmemente por la senda hacia la Verdad están exactamente en la misma posición que los hombres que la hicieron. O por expresarlo de otra manera, como en el Océano de la Unicidad divina no existen ni el 'yo', ni el 'tú', ¿qué sentido tendría 'hombre' y 'mujer'?" (Nurbakhsh, 1999: 19).

La discrepancia entre hombres y mujeres en dicha búsqueda radicaría, a mi entender, en la diferencia de los presupuestos de partida y en la dificultad que pudo encontrarse quien siendo mujer intentó su realización espiritual: cómo lo hicieron, qué coste hubieron de pagar y qué normas debieron romper, comparativamente hablando, para llegar al mismo lugar.

Entiendo que el camino de las mujeres debió ser más arduo y complejo, en tanto que criaturas limitadas en la disposición de su cuerpo, de su movilidad, de la posesión de bienes, etc. A ello había que añadir la perplejidad ante la que se tenían que encontrar situadas en un cuerpo que precisaba, teóricamente, mediación para llegar a Dios. En un cuerpo impuro que debía ser velado a los ojos porque inducía al deseo y a la perdición y un cuerpo que en ocasiones ni siquiera era aceptada por la divinidad para la repetición de su palabra o la adoración en su santuario. No podía hallarse un hombre y una mujer ante el mismo dilema puesto que el cuerpo, que, efectivamente, es lo que les sobra a los místicos y las místicas, no se hallaba en la misma categoría ni disposición ante Dios. No podían hallarse en el mismo punto de partida porque la mujer era considerada cuerpo y cuerpo expropiado.

Por supuesto que las conceptualizaciones de género son de esta época, pero la escritura y su interpretación tienden un puente que une aquel mundo con el nuestro y posibilitan su entendimiento. De hecho, si leemos atentamente los textos, veremos que hay una constante que no podemos dejar a un lado en este tema y es la necesidad de virilizar a las mujeres destacadas para darles valor. Una cuestión que también se daba en la Edad Media cristiana y que pueden rastrearse en numerosos autores ${ }^{13}$. No voy

13 Por ejemplo podemos recuperar el discurso del Condestable Álvaro de Luna quien, a lo largo de su obra, El libro de las claras y virtuosas mujeres, a pesar de que desea alabarlas, cuando encuentra en ellas alguna una virtud sobresaliente la cataloga de mujer viril, es decir, que manifiesta características que no le son asignadas genéricamente: "notable fecho, como de suso ser reza en su historia, mas era de varon que de muger" "...varoniblemente se defendió, poniendo por sí sus razones e escusaciones..." (Luna, 2002: 83 y 138; cfr. Arias Bautista, 2007: 59 y ss.).

De este concepto dicen Cuadra, Graña, Muñoz y Segura: "Los argumentos de la "mulier virilis" y de la excepcionalidad se han superpuesto en ocasiones para llegar a idénticos resultados de desautorización. El modelo de las mujeres que Milagros Rivera llama "de-generadas", es decir aquellas que viviendo en un cuerpo femenino poseían elementos de género masculino, ha servido para introducir sin demasiado peligro en el discurso histórico dominante a mujeres que alcanzaron niveles de conocimiento y sabiduría, fortaleza y santidad, no acordes con la supuesta inferioridad de su sexo..." (Cuadra, Graña, Muñoz y Segura, 1995: 43). elegir textos coránicos, que ya han sido suficientemente analizados, sino dichos sufíes, como el de 'Attâr, al referirse a Râbe'ah de Basora: "No era meramente una mujer, sino un verdadero hombre espiritual" (Nurkbahsh, 1999: 9). O, este otro, del mismo personaje: “ $\mathrm{O}$ Oh hombre, la primera persona en dar un paso al frente será María, la madre de Jesús!" (Nurkbahsh, 1999: 19).

Esa debilidad que convierte a la mujer en un ser inferior es manifestada por Sâleh, cuando hubo de reconocer la superioridad de Râbe'ah de Basora: "Soy un hombre, pero ignorante y tonto, mientras ella es una débil mujer, pero llena de sabiduría" (Nurkbahsh, 1999: 48). Las palabras aquí expuestas nos muestran claramente la oposición genérica a que vengo refiriéndome. En la afirmación “Yo soy hombre, ella es una débil mujer", sin otros adjetivos que, aun existiendo, califican posteriormente a ambos, encontramos la dicotomía en que el lenguaje traduce la desventaja de las mujeres con respecto a los varones.

Podemos hallar continuamente fórmulas que muestran el asombro masculino ante el desarrollo de capacidades femeninas objetivadas como singulares, es decir, no frecuentes. Esto es algo que perturba el equilibrio trazado, que viene a socavar los cimientos de una sociedad que ha de resolver el dilema en que ha situado a las mujeres: por un lado les ha privado de la posibilidad de manejarse como individuos autónomos $\mathrm{y}$, por otro, ha de reconocer que son capaces de alcanzar metas no trazadas para ellas, metas a las que quienes llegan, son sorpresivamente, iguales o mejores.

Este dilema a que se enfrenta el Islam se ha intentado resolver desde perspectivas bien diferentes a aquellas de las que yo parto. Así, por ejemplo, la ya citada profesora Murata, ve la masculinidad y la feminidad como una realidad dicotómica esencial a partir de la cual ha de explicarse la espiritualidad mística. Una dicotomía que no hace, a mi juicio, sino traducir el sistema de género impuesto por el androcentrismo patriarcal que ve a Dios como varón y divide las virtudes en masculinas y femeninas. Sachiko Murata señala que Dios, en el ejercicio de sus potencias es masculino y aborda el lado femenino cuando recibe a sus criaturas. Veamos sus palabras:

Por regla general, para el pensamiento islámico la masculinidad es una cualidad de la actividad, control, autoridad, dominación fuerza, poder, grandeza. La feminidad muestra las cualidades complementarias: receptividad, asentimiento, sumisión, entrega, debilidad, cesión, tolerancia, humillación... Dios por tanto tiene cualidades masculinas como femeninas... Dios es femenino en su propio ser, en lo que la teología islámica llama su esencia... Cada nivel sucesivo de descenso de Dios hacia el mundo es femenino en relación con lo que precede y masculino en relación con lo que lo sigue... Las mujeres de luz son los seres humanos, sean masculinos o femeninos, que se someten libremente a los modos de obrar de Dios... Así pues, según el Corán ser un 
verdadero musulmán es someterse libremente a Dios y tener receptividad para todo lo que Dios da. Lo primero que se pide a alguien que quiera ser un verdadero musulmán es que sea una mujer en el sentido en que estoy usando esta palabra. No se puede ser plenamente humano sin entregarse completamente a Dios, es decir, no se puede ser plenamente humano sin actualizar la luz de la feminidad... Las dificultades surgen en nuestra situación humana cuando no somos capaces de entender que por naturaleza somos mujeres. O nuestros problemas se deben a que intentamos ser varones cuando en realidad somos mujeres. En relación con Dios todos los seres humanos tienen que elegir ser mujeres. El modo de hacerlo es reconocer nuestra naturaleza femenina, receptiva y creada tal como es (Murata, 2001: 276 y ss.).

Naturalizar como inmanentes a la masculinidad o la feminidad ciertas virtudes o comportamientos se aleja con mucho de mis presupuestos mentales. Virtudes y comportamientos no se adhieren a la piel de hombres y mujeres desde el nacimiento, sino que son producto de una elaborada formación identitaria en la que tiene mucho que decir el Habitus ${ }^{14}$.

Un análisis similar al de Murata realiza, Su'âd Hakim, especialista en el estudio de sufismo y del pensamiento islámico, cuando desentraña la ideología de Ibn Arabi sobre las mujeres. La autora entiende que en este autor sufí existe una mujer individuo, no del todo apta para lo que el hombre ha sido dotado, y otra mujer que en esencia tiene capacidades y potencias espirituales para allegar los más altos grados de santidad. De ahí, dice Su'âd, que Ibn Arabi hable de su maestra con estas palabras: "uno de los más grandes virtuosos que actuaba libremente por el mundo del espíritu" (Hâkim, 2001: 188-190). Defiende que en Ibn Arabi la humanidad es el atributo esencial del ser humano y la virilidad y feminidad son accidentales (Hâkim, 2001: 192). Siguiendo su análisis, para Hakîm, Ibn Arabi no hizo sino recuperar los planteamientos de los primeros tiempos del Islam en los que las mujeres estaban involucradas en las ciencia y la política de forma clara, pública y directa (Hâkim, 2001: 94-195). Por ello Ibn Arabi diría: "Estar enamorado es labor de hombres, pues el que busca al Señor es un hombre".

Como vemos ambas investigadoras se ven impelidas a dar explicación de esa catalogación de virilidad que se atribuye a los elementos femeninos que, superando su condición de inferioridad y subordinación, llegan a límites no previstos. Veamos, ahora, algunos ejemplos de sufíes, en los que existe la necesidad de darse explicaciones a una realidad que no era la que en aquel tiempo se interpretaba:

Si estas que recordamos son mujeres

Entonces más que cien hombres valen

Que el sol sea femenino, no significa nada,

14 Uno de los principios de la teoría de la socialización de la identidad diferencial de género que puede seguirse en la obra de Bourdieu (2000).
Ni honor el que la luna sea un nombre masculino ${ }^{15}$.

Déjate de una vez de historias y dedícate a Dios como un hombre, día y noche, a igual que Râbe'ah ${ }^{16}$

Quien desee ver a un hombre verdadero disfrazado de mujer, que mire a Fátima ${ }^{17}$. Ella vivía en Marchena de los Olivares, donde iba con frecuencia a visitarla. Entre Ell vivia en Mre los hombres espirituales, nunca he conocido a nadie que tuviera semejante dominio de su alma (Ibn Arabi, 2007. 197).

Este andar de lo masculino a lo femenino, del hombre a la mujer, necesario para explicar tantas imposiciones y prejuicios estructurales que minusvaloran a las mujeres y sobrevaloran a los varones era ciertamente captado por las mujeres sufíes. En cumplimiento de las exigencias de subordinación con respecto a las mujeres, ellas van exigir de los hombres la demostración de su hombría:

Hosein Ibn Mansur Hallây tenía una hermana que declaraba su hombría en la senda sufí, y que era bastante atractiva. Al entrar en Bagdad, tapó la mitad de su rostro con el velo, dejando la otra mitad descubierta y sin velo. Un hombre la vio y le preguntó ¿Por qué no te tapas todo el rostro? Muéstrame un hombre, y cubriré totalmente mi rostro, contestó. Sólo hay la mitad de un hombre en Bagdad y se trata de Hosein. Si no fuera por él, ni siquiera taparía esta mitad ${ }^{18}$

Existe una protesta de las mujeres hacia las imposiciones que las coartan, como podemos interpretar de la expresión siguiente, que debemos a Yâmi, Nafahât al-Ons: "Desde que Le conocí, no he tenido velo ante mí" ${ }^{19}$. O el relato sobre un acontecimiento en la vida de Râbe'ah:

Said ben Utman nos contó lo siguiente: Estaba yo con Dhû'n-Nûn al-Misrî (considerado por algunos sufíes como padre de la mística)... y vimos a alguien (considerado por algunos suffes cono padre de la mistica)... y vinos a alguien acercarse. Dije a mi compañero: -Maestro, viene alguien. -Mira quién es. Fui a ver y constaté que era una mujer. -Es una mujer-le dije- una amiga de Dios, ¡Por el Señor de la Kaaba! El se dirigió hacia ella y la saludó. Ella le dijo: - ¿Conviene a los hombres saludar a las mujeres? -Soy tu hermano Dhû'n-Nûn. No se podría sospechar de mí. Sé bienvenido,-dijo entonces ella- ¡Dios te de la paz! (Râbi'a AlAdawiyya, 2006: 83-84).

En consecuencia aunque se pregona esa igualdad teórica del creyente y la creyente, aunque algunos sufíes consideren que hombres y mujeres tienen iguales posibilidades de acceder al conocimiento de Dios, y de hecho accedieron, yo intuyo que las mujeres sufíes debieron sortear no pocas lagunas para llegar a iguales metas que sus compañeros

15 Palabras del poeta y sufí persa Yâmi en su libro "Los alientos de la intimidad" (Nurbakhsh, 1999:

16 'Dicho de 'Attar (Nurbakhsh, 1999: 21).

17 Palabras de Bâyacid Bastâmi, referidas a Fátima ó Omm ‘Ali (Nurbakhsh, 1999: 78).

18 Noticia sobre Hanunah, hermana de Hallây (Nurbakhsh, 1999: 154).

19 Yâmi, Nafahât al-ons, (Nurbakhsh, 1999: 166). 
varones. Ellas eran conscientes de estas limitaciones desde los primeros tiempos, como se pone de manifiesto al repasar la vida y dichos de Râbe'ah de Basora y de otras místicas. En el primero de los casos citados rescataremos una anécdota respecto a su vida. Al parecer, unas personas, para poner a prueba su piedad le dijeron:

Dios ha coronado la cabeza de sus Amigos y les ha prodigado la gracia de los milagros. Sin embargo, ninguna mujer ha accedido jamás a ese rango ¿Cómo lo has conseguido tú? Râbe'ah les contestó: Es cierto lo que decís. Pero el orgullo, la mentira y la absurda pretensión de divinidad jamás tuvieron su origen en una 2006: 102).

\subsection{El problema del reconocimiento}

¿Cómo puede reconocerse una mujer de la que para nombrarse se ha apartado todo lo femenino pues este carece de valor? Siguiendo la costumbre coránica en la que las mujeres no son citadas por sus nombres, sino que aparecen como la mujer de, la hija de, la hermana de... Son muchos los ejemplos a señalar a este respecto en las biografías de mujeres sufíes. Bastará con uno para hacerse una idea de lo que refiero:

\begin{abstract}
De las santas mujeres sufíes que alcanzaron estados elevados en la Senda, Râbe'ah de Siria es una de las más conocidas. Era hija de Esmâil de Siria y esposa de Ahmad Ibn Abi al-Hawâri, conocido también como Abu'l Hasan o Maimun, que era originario de Damasco y murió en 845 . Su padre era contemporáneo y compañero de algunos de los grandes maestros sufíes de su tiempo, como Abu Soleymân Dârâni... El hermano de al-Hawâri, era conocido por su ascesis y desapego, y su hijo ‘Abdo'llâh, fue un asceta muy conocido (Nurbakhsh, 1999: 67).
\end{abstract}

Aparte de no tener referente femenino al que acercarse, pues sólo los hombres son citados en la genealogía de hombres y mujeres, ¿cómo puede caminar con la misma seguridad un varón que nada tenía que guardar, que una mujer que necesariamente debía permanecer oculta al mundo y a los hombres que no fueran su marido?: "Cierra tus ojos Zolnun. Te está prohibido mirarme. Sus palabras me hicieron recordar que era una mujer. Tratando de disculparme dije: Juro por Dios que tus palabras me habían abstraído tanto que no era consciente en absoluto de que eras una mujer" (Nurbakhsh, 1999: 162).

O cuando encontramos expresiones de varones como la siguiente: "antes de conocer a Omm 'Ali, nunca me había gustado escuchar relatos sobre las mujeres"20. Mujeres que aunque reconocidas seguidoras del camino por sus compañeros o por sus esposos, debían estar vigilantes a como se mostraban, a como las veían, a lo que pudieran decir de ellas..., tal y como ocurrió a esta misma Omm 'Ali, que sentía que la espiritualidad

20 Palabras de Abbu Hafs Haddâd (Nurbakhsh, 1999: 78). estaba por encima de todas las cosas materiales y por ello, aún a disgusto de su marido, sufí como ella, se mostraba sin el velo ante quién ella entendía era su maestro y consejero espiritual. Un consejero del que hubo de prescindir precisamente en cuanto éste consideró en ella su condición femenina:

Al reunirse con Bâyazid, Fatima quitó su velo sin inmutarse y, sentándose se puso a conversar ante él abiertamente. Ahmad estaba asombrado y se puso celoso en su corazón. ¿Cómo puedes ser tan descarada con Bâyazid?, le preguntó su marido más tarde. Fátima le contestó: Tú eres el confidente de mi naturaleza, y mi consorte, Bâyazid es mi confidente espiritual. Por medio de ti alcanzo mi satisfacción física por medio de Bâyazid a por medio de Bâyazid alcanzo a Dios. El hín y tú si, lo demuestra. Fátima siguio comportandose libremente con Bâyazid hasta que, un día, observando el tinte de su mano, éste le preguntó: ¿por qué pones henna en tus manos? Reprendiendo a Bâyazid dijo: Me sentía totalmente libre contigo Bâyazid, mientras no eras consciente de mí, ni de mis manos y su tinte. Pero ahora que tus ojos han empezado a observar mis manos, toda comunicación entre nosotros está prohibida (Nurbakhsh, 1999: 79).

\subsection{Relación entre su corporeidad y Dios. Cuerpo alienado para sí}

La mayoría de las místicas sufíes, como sus compañeros varones, se caracterizan por el ascetismo. Por medio de la oración, la vigilia, el ayuno y el dolor físico, buscaban la aniquilación del yo (nafs) para merecer la unión con Dios: “Este nafs mío, encerrado en mi cuerpo, es mi mayor dolor" ${ }^{21}$. Pero hubo algunas, que llevaron su ascesis al rigor extremo, multiplicando las oraciones y lo que ello significa: levantarse, arrodillarse y postrarse con cada una de ellas ${ }^{22}$; realizando ayunos prolongados o vitalicios que les dejaban la piel pegada a los huesos ${ }^{23}$. Por ello, el hecho de notar que su cuerpo

\footnotetext{
21 Tohfah, esclava juglar, muerta en 857 (Nurbakhsh, 1999: 89)

22 “Solía postrarse cada día 600 veces en oración”. Mo’Âza 'Adawiya (Nurbakhsh, 1999: 142).

"Se dice que cada día realizaba mil rak'at de oración ritual". Râbe'ah de Basora (Nurbakhsh, 1999: 25).

23 "Jansa era una sana del Yemen, una mujer libre de ataduras. Mantuvo un ayuno de cuarenta años, de modo que su piel estaba pegada a los huesos. Lloró tanto que sus ojos perdieron la vista, y pasó tantas noches velando y rezando que ya no podía tenerse en pie" (Nurbakhsh, 1999: 103). "Se había vuelto negra de tanto ayunar, había perdido la vista de tanto rezar, sus piernas ya no la sostenían y tenía que arrodillarse para orar... Lo que conozco de mi yo interior irrita tanto a mi corazón, que por Dios desearía que no me hubiese creado y que nunca hubiera sido nada digno de mención". Hechos y dich"o de Zoylah 'Âbedah. Ibídem., p. 109. "Vi a una mujer delgada como una varita de incienso. Llevaba ropas de lana y un velo tejido con cabellos. Se había agotado en la lucha interior y el dolor la había destruido. El amor la había disuelto y el éxtasis la había aniquilado". Zâhra, conocida como la ebria de Dios (Nurbakhsh, 1999: 109). "Al mirarla detenidamente, la mujer se dio cuenta de que Ayrâdah estaba en los huesos... Había estado ayunando sin cesar durante sesenta través del ayuno". Nafisa (Nurbakhsh, 1999: 151). "El hambre se había cobrado su tributo en ella". Hija de Omm Hasan Asadiya (Nurbakhsh, 1999: 156).
} 
tenía carne les hacía sufrir ${ }^{24}$. Las mortificaciones y vigilias constantes ${ }^{25}$ les conducían a la aniquilación ${ }^{26}$, a la muerte ${ }^{27}$, o a una especial predisposición orgánica para el anonadamiento ${ }^{28}$, idea ésta última de Ana Iribas.

Dios arranca a las criaturas de su materialidad y de su mismidad: “Tú que desde el primer día, me robaste de mí misma" ${ }^{29}$. Hasta el punto de no hallarse en nada ni explicarse su existencia: "Dime que soy, quien soy y porqué soy"30. Y de haber formado un todo con Dios: "Colmados de tu rapto están mi corazón y cada miembro de mi cuerpo" ${ }^{31}$. Es entonces cuando recobran su identidad: “Mi ser profundo y mi bella imagen, son como una sola alma enfundada en dos cuerpos. Un solo ser llamado por dos nombres"32. "Cuando mi anhelo lanza llamaradas, / mi corazón se abisma en tu recuerdo... / Cuando Él se manifiesta, / Me desvanezco en Él, para en Él volver a revivir" ${ }^{33}$. "Tú amor... / Se ha acabado fundiendo con mi carne, mi sangre y mis huesos" 34 .

Muchas mujeres sufíes son recordadas anegadas en llanto continuo: "Era tal su estado espiritual que no podía pasar una hora sin que gimiera"35. “El lugar donde se encontraba parecía estar inundado por el agua de sus lágrimas" ${ }^{\prime 36}$. Llanto que en

24 "Escatimo a mi nafs cualquier comida sabrosa, y me aflijo cuando veo que mis brazos están rollizos". Dicho de Râbe'ah de Siria (Nurbakhsh, 1999: 71).

25 “No podía nunca dormir ni comer y pasaba las noches llorando y gimiendo". Tohfah (Nurbakhsh, 1999: 87). "Durante sesenta años, durmió solo en la alfombra de oración". Fátima de Egipto (Nurbakhsh, 1999: 131). “Râbe'ah solía pasar las noches rezando y solo se permitía dormir un poco antes del amanecer hasta que las luces del alba teñían el horizonte". Râbe'ah de Basora (Nurbakhsh 1999: 524).

26 “Aníquila tu ego, quémalo". “Arrójate en la hoguera del amor como una mariposa ¡Oh corazón! sé mariposa, mariposa". Palabras de una poesía de la princesa Zobayda (Nurbakhsh, 1999: 107) "Juro por tu magestad y por tu gloria que te serviré hasta que no quede de mí ni nervios, ni huesos". Oración de Hayyuna (Nurbakhsh, 1999: 101).

27 “El anhelo de Dios la mató". Zâhra, conocida como la ebria de Dios (Nurbakhsh, 1999: 110).

28 Esta tesis es defendida por quienes entienden que el someter al cuerpo a ciertas situaciones límite, altera la química orgánica general proporcionando estados especiales, similares a los conseguidos, con sustancias psicotrópicas (Iribas, 2001: 216-217)

29 Tohfah (Nurbakhsh, 1999: 91).

30 Tohfah (Nurbakhsh, 1999: 91).

31 Tohfah (Nurbakhsh, 1999: 904).

32 Dama Sakina Shirâz (Nurbakhsh, 1999: 111).

33 Una mujer que circunvalaba la Kaaba (Nurbakhsh, 1999: 178).

34 Una doncella en la orilla del río (Nurbakhsh, 1999: 169).

35 Una mujer en la Meca (Nurbakhsh, 1999: 182).

36 Esto se dice de Râbe'ah (Nurbakhsh, 1999: 61) el peor de los casos les provocaba la ceguera: “Lloró tanto que sus ojos perdieron la vista" $^{\prime \prime 3}$. Y que ellas mismas explican:

Estaba tan ahogada en llanto que nunca pude entender sus sermones... No puedo recordar ninguna de sus palabras, excepto esta declaración: quienquiera de los presentes que pueda llorar, debe hacerlo y si no debe compadecerse de las lágrimas de los demás. Porque todos los que aquí lloran, lo hacen por ser conscientes de hasta qué punto su yo inferior los ha contrariado y confundido por entender como sus pasiones los han convertido en transgresores ${ }^{38}$

Llanto derramado por la pena de sus transgresiones, por su alejamiento de Dios, llanto que liquida su organismo, lo vacía: “Juro por Dios que me gustaría llorar hasta que no me quedaran lágrimas. Luego derramaría una lluvia de sangre tal que no quedara en mi cuerpo ni una gota" ${ }^{39}$.

El padre de Sha'Wâna, mística a quien se atribuye este discurso sobre el llanto, preocupado por el estado de su hija, fue a peguntar a un santón el motivo de aquel inexplicable llanto que fluía sin parar cuando su hija oía cualquier mención de Dios. Toda su cara, dice, se anegaba y no se sabía de dónde procedían las lágrimas. El santón le contestó que: "Su temor de Dios viene de que todo su corazón está en llamas. Dicen que la cantidad de lágrimas que vierte una persona depende de la cantidad de fuego que tiene en su corazón" ${ }^{40}$.

Pero del mismo modo que el sufrimiento moral les embargaba los sentidos: “Cuando la vieron, experimentaron un gran temor reverencial, tanto por la luz que de ella se desprendía, como por el sufrimiento que soportaba" (Râbe'ah, 2006: 73), parecen estar ajenas al dolor físico ${ }^{41}$.

Alcanzada la meta espiritual su ser se ha convertido en un ser de luz, capaz de dar luz al resto de sus semejantes: “Râbe'ah no tenía lámpara y estaban sentados en

37 Jansa (Nurbakhsh, 1999: 103). “Estuvo llorando cuarenta años, hasta que al final le sobrevino la ceguera". Obayda (Nurbakhsh, 1999: 123)

38 Sha'Wâna (Nurbakhsh, 1999: 117).

39 Sha'Wâna (Nurbakhsh, 1999: 116).

40 Sha'Wâna (Nurbakhsh, 1999: 116).

41 "Sobresaliendo de su ojo derecho había una espina y unas gotas de sangre resbalaban por su mejilla hasta caer a la alfombra... Mi corazón estaba tan lejos de mí, que si todos los tormentos de todas las historias sobre el infierno se hubiesen puesto en la punta de una aguja, y ésta me la hubieran clavado en el ojo derecho, si mi ojo izquierdo se hubiese crispado por el dolor, lo habría arrancado de cuajo" Râbe'ah de Basora (Nurbakhsh, 1999: 49). "Se golpeó la cabeza con una piedra puntiaguda. Empezó a sangrar abundantemente, pero era completamente ajena a su situación... ¿no sientes dolor?... Mi dedicación a la realización de su divina voluntad evita que sienta lo que vosotros observáis". Râbe'ah de Basora (Nurbakhsh, 1999: 53-54) 
la oscuridad, Râbe'ah sopló suavemente sus dedos, que permanecieron ardiendo, haciendo de lámpara hasta el amanecer" ${ }^{\prime 2}$.

Esta espiritualidad ejemplar femenina no era bien recibida por todos y algunos la criticaban, pensando que lo hacían por llamar la atención: “Esa mujer se castiga a sí misma para protestar y llamar la atención sobre si" ${ }^{\prime \prime 3}$. Y yo me pregunto: ¿de qué tenía que protestar Râbe'ah?

El cuerpo, el cuerpo que es preciso cuidar y alimentar, cuerpo que en las mujeres está alienado y ha de vivir para otros, es descuidado y maltratado. El cuerpo les estorba ¿Sucedería a las místicas del Islam, como a las místicas cristianas que se negaban a alimentarse por el coste que les suponía ser cuerpo? ${ }^{44}$

\subsection{Relaciones con el mundo}

El rechazo del cuerpo para sí no es el único principio, ya que éste va acompañado del rechazo a todo lo material y eso comprende al mundo en general y todo lo que representa. El desapego es vivido de distintas formar por las diferentes mujeres sufíes. Ya dije que unas eran esclavas y lo fueron toda su vida, cantando entonces a la libertad de sus cadenas en Dios, como Tohfa que lo fue durante muchos años de su vida hasta que fue liberada, al igual que Râbe'ah. Tenemos noticias de quienes fueron grandes señoras y vivieron dentro de su estrato social, aunque despegándose en lo posible de lo material. Otras trabajaron por amor a Dios, sin cobrar nada ${ }^{45} \mathrm{y}$ las hubo que se procuraron su sustento con la obra de sus manos o bien cultivando lo que precisaban en el entendimiento de que no sabían de dónde procedía el dinero de las ofrendas y temían fuese dinero contaminado ${ }^{46}$, o por propio compromiso personal: "Llevaba una capa de lana en la que había escrito: nunca compraré ni venderé nada ${ }^{47}$. Pero, la inmensa mayoría terminaron sus días viviendo de la caridad, de las sobras de las

\section{Râbe'ah de Basora (Nurbakhsh, 1999: 35).}

43 Râbe'ah de Basora (Nurbakhsh, 1999: 35).

44 Las diferentes teorías sobre la anorexia femenina, claro está referidas al contexto cristiano, aparecen formuladas en la obra de Milagros Rivera. Así, por ejemplo, para Caroline W. Bynum el rechazo de la comida y el sufrimiento que esto comportaba, era en el fondo un acto de identificación total con el rol atribuido a las mujeres de nutridoras del grupo. Las mujeres así se convertían con el alimento místico, en una versión más plena de la comida y la carne que en su cultura se daba por supuesto que ellas eran. Al unirse a Cristo, la mujer se convertía en un ser todo carne y capacidad nutricia, hecha una con el sufrimiento generativo de Dios. Mientras que para Rudolph Bella la explicación vendría dada por una relación con el pecado. Ya que, como a las mujeres medievales se les había inculcado que el pecado estaba en el interior de ellas mismas, la anorexia sería una forma extrema de negación a un tiempo del pecado y del propio cuerpo (Rivera Garretas, 1990: 60 y ss.).

45 Como Omma Ahmad que ejercía de comadrona sin cobrar nada por ello (Nurbakhsh, 1999: 75).

46 “Porque no utilizaré nada que no venga de mi propio trabajo o del de mi padre. No cogeré ningún dinero cuyo origen desconozco". Hija de Abol Hasan Maki (Nurbakhsh, 1999: 155).

47 Maymuna Siya (Nurbakhsh, 1999: 144).

ISSN $1885-3625$
Revista Internacional de Cultrasy gentes o de lo que recibían de Dios, como las que ordeñaban la leche de cabras u ovejas especialmente santificadas ${ }^{48}$.

El vagabundeo como medio de vida, que muchas sufíes llevaron a cabo: la propia Râbe'ah de Basora, por ejemplo, lo ejerció durante algún tiempo, no era sino una ruptura con la norma que obligaba a las mujeres al aislamiento en el interior de los muros de una casa, bajo la atenta vigilancia de los varones de la misma y de los que eran dependientes: padre, marido, hijo...

Muchas de sus actitudes fueron escandalosas para la comunidad, en tanto en cuanto, las mujeres tampoco debían llamar la atención sobre ellas. Por eso, aún siendo generalmente respetadas, en ocasiones, recibían la burla, el rechazo e incluso el maltrato físico $^{49}$ o psicológico ${ }^{50}$ de otras gentes, ya se tratara de grandes personalidades o no.

Algunas fueron tildadas de locas, forma más fácil de explicar que con su comportamiento eludían todas las reglas sociales ${ }^{51}$. Su modo de obrar no era sino el espejo en el que los demás necesariamente se miraban y veían la diferente dimensión entre la entrega de estas místicas a Dios y la que profesaba el resto.

Muchísimas se aislaron del mundo y la mayoría mostraba una total indiferencia hacia él, algo inusitado en las mujeres que debían vivir su vida para los demás, ajenas a ellas mismas y a sus deseos. Ninguna persona era capaz de llamar suficientemente su atención y eran diestras de despegarse de los afectos sin el más mínimo resquemor ${ }^{52}$ Este alejamiento podía llegar al punto de desear la ruptura definitiva, la muerte ${ }^{53}$. Nada había capaz de distraerlas de su principal objetivo: la perfección y la búsqueda de la

48 "Se llamaba Fedha. Al llegar al pueblo me dijeron que tenía una oveja que daba leche perfumada" (Nurbakhsh, 1999: 134).

49 "Vi a una joven negra apedreada por un grupo de chiquillos". La joven negra (Nurbakhsh, 1999: 166).

50 "Muérete tú que estás bajo el velo". Una mujer en la asamblea del maestro Shebli (Nurbakhsh 1999: 174)

51 "El amor de Dios los ha vuelto perplejos, hasta tal punto que la gente los tiene por locos y todo lo que saben les ha causado aflicción" (Nurbakhsh, 1999: 183). "Una devota que se había vuelto trastornada por el amor". Ibídem., p. 188. "Me llegaron noticias de que en las montañas de Moqattam vivía una mujer especialmente piadosa... Deseaba hacerle una visita... iquieres abandonar la compañía de los sabios y hacerte amigo de los locos?... Finalmente me dijeron: Pasa por aquí a menudo. A veces la vemos permanecer inmóvil y chillando, otras veces llora, otras están callada y a veces se ríe... Zolnun su amor me ha vuelto loca" (Nurbakhsh, 1999: 160).

52 “He roto tan absolutamente mis lazos con la gente que, al caer el día, por miedo a que alguien pueda distraerme o penetrar en mi corazón, rezo así: Señor comprométeme sólo contigo, para que nadie pueda distraerme de Ti". Râbe'ah de Basora (Nurbakhsh, 1999: 39).

53 "Estoy tan hastiada de la vida que si hallara a alguien que vendiera muerte, la compraría". Una dama anónima (Nurbakhsh, 1999:186). 
unidad divina ${ }^{54}$. Y ello porque como decía ‘Âtekah Qanuyah: “El mundo es impuro en la mente de aquel que lo ha entendido" ${ }^{\prime 55}$.

Una vez superados los escollos del camino, su pobreza queda trocada en riqueza, superior a la que cualquiera pudiera poseer, como manifestaba Mâmâ 'Esmat: “Entré como un mendigo en la pobreza, / sin capital, sin pertenencia alguna / ahora vendo las perlas y las joyas / que están en el mercado de la nada"56.

Nuevamente una rebelión, una negación de lo que se estimaba que eran las mujeres siempre apegadas a las joyas, a los vestidos y a su necesidad de mostrar al mundo su belleza. Y es, en ese momento, de la anulación del cuerpo y del mundo cuando ellas vuelven a aceptar la relación consigo mismas. Son sugerentes en este punto las palabras de una sufí de quien no conocemos el nombre: "Renunciando a los deseos, los cuerpos se vuelven ligeros y los actos, abandonando toda expectación, se vuelven agradables" ${ }^{\prime 57}$

Muchas tuvieron discípulos y discípulas. Otras, por el contrario, no querían relacionarse con los seres humanos, como hemos visto que sucedía a Râbe'ah de Basora, que temía perder la intimidad con Dios, contaminarse con los afectos de este mundo: “No dejo salir lo que está en mi, ni permito que lo que está fuera de mi entre. Si alguno entra, va y no tiene nada que ver conmigo. Yo protejo el corazón, y no soy el cuidador del barro" (Nurbakhsh, 1999: 45).

Râbe'ah no se reconoce cuidadora del barro, es decir la criatura humana. Se desliga de esa función tradicional a la que el patriarcado ha condenado a las mujeres. Al afirmarse como espíritu anegado en Dios, ajeno a la carne, ya no ha de cumplir tal función que la alejaba de sus deseos, de su estado superior. Su amor a Dios era tan excluyente que llegó, incluso a manifestar que en su corazón no existía lugar para el amor a Mahoma, con lo que esta declaración tenía de rebeldía a los dictados más trascendentales de la Ley Islámica: "Mi corazón está tan totalmente traspasado de amor por Dios, que no queda sitio en él para amar u odiar a otro" (Nurbakhsh, 1999: 45). En otro lugar dirá: “El amor a Dios me inhibe del amor por sus criaturas" (Nurbakhsh, 1999: 46). No respeta tampoco la adoración a la Kaaba, a la que considera un centro de adoración vacío de contenido: “Ahí está la casa, el gran ídolo en la tierra, pero Dios ni está en ella ni fuera de ella" (Nurbakhsh, 1999: 53).

54 “Nunca he deseado nada de este mundo... me resulta molesto dedicar mi tiempo a otra cosa que a Él”. Omm Hêsan (Nurbakhsh, 1999: 77). "Nada en este mundo o en el otro me proporciona ninguna satisfacción, si Tú no estás en ello". Thawbiyah, hija de Bohlul (Nurbakhsh, 1999: 97). "No tenía pertenencias en su casa y cuando tenía sed iba a un riachuelo cercano y bebía cogiendo agua entre sus manos". Hasana 'Abedah (Nurbakhsh, 1999: 97).

55 'Âtekah Qanuyah (Nurbakhsh, 1999: 122).

56 Mâmâ 'Esmat (Nurbakhsh, 1999: 138)

57 Una doncella a orillas del Nilo (Nurbakhsh, 1999: 169).
Hubo otras Râbe'ah, absolutamente despegadas de la amistad y del amor humano. Sin embargo, como ya he dicho, algunas sufíes fueron grandes maestras tanto de hombres como de mujeres. Tenían formación como juristas, como Bahriya ${ }^{58}$, eran respetadas por la comunidad y dirigían asambleas tanto de varones como de mujeres ${ }^{59}$.

Existe un reconocimiento a los dones, milagros y carismas de muchas de ellas ${ }^{60}$, de tal modo que se les permitía amonestar a los desviados bien fueran hombres o mujeres y ocuparan el rango que ocuparan. Algo que por principio no podía ser aceptado pues eran los hombres los destinados a corregir a las mujeres y no al revés.

Tema igualmente irregular es el de su estado civil y el de las relaciones sexuales. Como indiqué al principio unas estuvieron casadas y otras no y otras mantuvieron relaciones sexuales por el hecho de ser esclavas y deberse a sus amos ${ }^{61}$. El cuerpo de las mujeres es cuerpo para la obtención de placer de los varones, como igualmente he dejado dicho en las líneas que anteceden. Ahora bien, pueden analizarse dos posturas diferentes en las relaciones entre hombres y mujeres en el pensamiento sufí y que, a diferencia de lo que ocurre en el cristianismo, la virginidad les es ajena y difícilmente concebible.

Una postura en la de Râbe'ah de Basora, contraria al matrimonio frente a toda insinuación sobre el mismo. Según los relatos de su memoria, en varias ocasiones se le propuso matrimonio o se le instó a ello. Siempre lo rechazó. En primer lugar tuvo una oferta del gobernador de Basora, a la que respondió indicándole que sería imposible desviar ni un ápice la atención de Dios para mirarle a Él (Nurbakhsh, 1999: 25). E gobernador de Bagdad solicitó también que fuera su esposa y la respuesta fue similar.

58 Bahriya (Nurbakhsh, 1999: 83).

59 "Una de las discípulas de Sha' wana contaba que desde el momento en que puso su mirada en ella, gracias a su poder carismático, nunca más volvió a sentir inclinación hacia lo mundano" (Nurbakhsh, 1999: 117). "Vivía en Marchena de los Olivos... tenía un corazón fuerte y puro, un noble poder espiritual y un fino discernimiento... estaba dotada de muchos dones" (Nurbakhsh 1999: 119). "Fátima de Bagdad destacaba como juez, jurista, maestra, erudita, piadosa, asceta y sufí... Además de dirigir un pequeño círculo de mujeres, a las que enseñaba, solía también a menudo subir al púlpito para dirigir sermones públicos" (Nurbakhsh, 1999: 131-132). Halima de Damasco fue la maestra de Râbe'ah de Siria (Nurbakhsh, 1999: 98).

60 “Fajr, conocida como el orgullo del género femenino... Era una mujer piadosa y recta. La Râbe'ah de su tiempo y realizó muchos actos carismáticos. Era una discípula fiel de Rumí e iba mucho a visitarle" (Nurbakhsh, 1999: 128). "Mâmâ 'Esmat era la corona de las gnósticas de su época, muy elogiada y profundamente venerada por su santidad entre los companeros de la virtud. Había alcanzado moradas espirituales extraordinariamente elevadas y experimentado maravillosos estado místicos..." (Nurbakhsh, 1999: 136).

61 Estaba en una ocasión profundamente enamorado de una de mis esclavas. Me desperté una noche y descubrí que no estaba a mi lado" (Nurbakhsh, 1999: 153). 
Hubo otras místicas que reaccionaron del mismo modo ante la posibilidad de contraer matrimonio, como es el caso de Aluf Mawseli6 ${ }^{2}$. Un caso peculiar es el de Hasana, a quien una mujer animó a casarse y contestó: "Si me presentas a un hombre de carácter ascético, que no me distraiga con los asuntos del mundo, lo consideraré pero, alguien así pienso que es difícil de encontrar. Juro a Dios que no es mi naturaleza el adorar al mundo o el divertirme y distraerme con los hombres" (Nurbakhsh, 1999 98). Lo que puede ser traducido por un rechazo absoluto a su condición de cuerpo de mujer para la diversión.

Otras místicas critican a los hombres que dispusiesen de tiempo para dedicarse a las mujeres en lugar de hacerlo a la oración y a $\operatorname{Dios}^{63}$. Al otro lado de este espejo se encuentran las místicas que estuvieron casadas y se comportaron como buenas esposas, acicalándose para el placer de sus maridos, como establecía la Ley y dedicándose a la oración tras cumplir con su débito conyugal: Cada noche Râbe'ah se perfumaba y se presentaba a su marido preguntándole si
tenía alguna necesidad. Si las tenía, las satisfacía. Luego se separaba de él, hacía sus abluciones y se quedaba orando hasta el amanecer (Nurbakhsh, 1999: 70).

Tras realizar sus oraciones, la mujer de Râba se lavaba y adornaba, cambiaba Tras realizar sus oraciones, la muj su ropa y se acercaba a su marido para preguntarle si deseaba algo de ella. Si contestaba que no, volvía a vestirse como de costumbre, y se quedaba rezando hasta el amanecer (Nurbakhsh, 1999: 152).

Hubo, incluso, algunas mujeres que buscaron ellas mismas el matrimonio proponiéndolo al hombre que les interesaba, aquel que estimaban no iba a estorbar su relación con Dios, lo que también supone una situación contraria a la costumbre. Este fue el caso de Râbe'ah de Siria, cuyo matrimonio por interés, a su propuesta, parece distorsionar el matrimonio musulmán. Al parecer ya era viuda y se interesó por al-Hawari: "Brindé mi cuerpo a quien ansiaba estar conmigo, / vi ese cuerpo aceptable / para sentarme junto a él, pero mi Amado / es el único dueño de mi corazón" (Nurbakhsh, 1999: 69).

Râbe'ah de Siria mantuvo relaciones con su esposo hasta que, en un momento dado dejó de estimar necesario hacerlo: “Cuando intentaba acercarme a Râbe'ah por el día, me rogaba, en nombre de Dios, que no la obligara a romper su ayuno. Por las noches, si me aproximaba, me pedía que le dejara dedicar la noche solo a Dios" (Nurbakhsh, 1999: 70).

62 "Dile que aun cuando fuese mi esclavo, y todo lo suyo me perteneciera, nunca podría distrae mi atención de Dios" (Nurbakhsh, 1999: 74). "Sufyan Suri quería ser esposo de Omm Hesân... Te aseguro Sofian que me resulta molesto dedicar mi tiempo a otra cosa que a Él" (Nurbakhsh, 1999

63 Malika, hija de Monkader (Nurbakhsh, 1999: 145-146).
El esposo de Râbe'ah de Siria tomó entonces tres esposas más y a ella no le importaba seguir cocinando para él. Incluso, en un momento dado, le sugirió que tomase otra esposa o se comprara una esclava, facilitándole ella el dinero para la dote o para la compra. Si bien puede estimarse que este comportamiento coadyuva a la existencia de la poligamia y a manifestar que una santa estimaba necesario que su marido tuviese más esposas, lo cierto es que al ser idea de ella y ser ella la que le rogaba que la dejase en paz el análisis puede reconducirse por otras vías. Otro ejemplo de mujer que inició los trámites para su matrimonio fue Omm'Ali, quien mandó un mensajero a Ahmed diciendo que pidiera a su padre su mano para casarse con ella (Nurbakhsh, 1999: 7879).

\section{Conclusiones}

Estimo que debió ser difícil sortear los cuerpos dibujados por el habitus con todas sus connotaciones, pues cada individuo parte hacia cualquier conocimiento arrastrando el lastre de sus vivencias particulares, enseñanzas, emociones, sentimientos, pensamientos; en una palabra, de la experiencia consigo mismo y con su entorno. Un místico o una mística no son papeles en blanco que se entregan a Dios para que ponga sobre él sus letras doradas, sino que intentan llegar a serlo. Entre tanto, la feminidad tiene impresa, desde hace milenios, una escritura muy determinada con renglones torcidos. Las místicas de aquí y de allí, en cualquiera de las religiones, tuvieron necesariamente que superar su yo individual para lograr la trascendencia pero, para ello, hubieron de sobrevolar por encima de sus limitaciones femeninas, saltando sobre los prejuicios atados a su sexo, los tabúes, las diferentes normas orales y escritas, y elevarse por encima de ellas hacia el infinito.

A la vista de todo lo expuesto podemos decir que aunque muchas sufíes se mantuvieron dentro de los cánones fijados para las mujeres, otras rompieron dichos cánones, manifestaron su rebeldía al negarse a ser cuerpo sexuado, al negarse a participar de lo que el mundo o los seres humanos podían ofrecerles y dieron ejemplo de un estar en el mundo de forma diferente.

Tales comportamientos dieron lugar a diversidad de posturas: el respeto y la admiración, pero, también, el maltrato o el desprecio por su locura. Salieron de los cauces de género establecidos para las mujeres y ocuparon espacios públicos. Solicitaron el matrimonio a los varones de su conveniencia, se mostraron sin velo, o se aferraron a él cuando ya no debían hacerlo para mantener las diferencias. El velo lo crearon ellas mismas con su actitud.

Algunas veces los severos y sesudos juicios de varones claramente afectados por su magnitud espiritual o intelectual fueron ridiculizados por ellas. Las sufíes, en general aparecieron como mujeres sueltas y capaces de elegir cómo había de discurrir su vida. 
Se mostraron inaccesibles, ajenas al mundo, a lo humano y a sus miserias. No brillaron por su amabilidad, sino por su lejanía. Usaron su cuerpo para dar cumplimiento a los preceptos externos, pero mostraron que dicho cuerpo les era ajeno. Si lo otorgaron a quién la ley les imponía, ellas se mostraron lejos de la ley.

Tenían el cuerpo empapado en llanto y el alma en llamas. Lágrimas derramadas por el alejamiento de Dios a causa de su naturaleza corpórea y la aspiración de trascendencia, de anegarse en la unicidad. Para conseguirlo el cuerpo les estorba por lo que lo mortificaron sin piedad con ayunos y vigilias de manera que quedaba poco apetecible a los ojos que las contemplaban. No cuidaban, no se cuidaban, renunciaron al cuidado. Sobrepasaron con su actitud la norma, sorprendieron e hicieron a los varones mirarse en el espejo. El ser humano prefiere colocar al otro lado de la frontera de lo cabal lo que le resulta inexplicable o ininteligible. El ser humano no comprende muy bien el alejamiento de la vida. Para ellas la vida era la muerte. Prefirieron morir para vivir y eso las diferenció del resto.

\section{REFERENCIAS BIBLIOGRÁFICAS}

Ait Sabbah, F., La mujer en el inconsciente musulmán, Ediciones del Oriente y el Mediterráneo, Madrid, 2000.

AA. VV. El Corán ayer y hoy. Perspectivas actuales sobre el Islam. Estudios en honor del Prof. Julio Cortés, Berenice, Córdoba, 2008.

Anawati, C.G. y Gardet, L., Mystique Musulmane. Aspects et tendances, experiences et techniques, VRIN, París, 1986.

Arberry, A. J., Le Soufisme. Introduction à la Mystique de L'Islam, Cahiers du Sud, Paris, 1952.

Arnold, T. y Guillaume, A., El legado del Islam, Pegaso, Madrid, 1958.

Arias Bautista, M. T., Violencias y mujeres en la Edad Media Castellana, ed. Castellum, Madrid, 2007.

Asin Palacios, M., El Islam cristianizado. Estudio del Sufismo a través de las obras de Abenarabi de Murcia, Hiparión, Madrid, 1981.

Bárcena, H., Sufismo, vía del corazón, Centre d’Estudi de les Tradicions Religioses,

Bize, H. G., El sufismo y la mística del Islam, https://www.webislam.com/articulos/39281-el_ Bourdieu, La dominación masculina, Barcelona, Anagrama, 2000.

Bukhari, S., 'Menstrual Periods', Volumen 1, Libro 6, Número 301.

Burckhardt, T., Esoterismo islámico, Madrid, Ed. Taurus, 1980.

Cahen, C., “El Islam I. Desde los orígenes al comienzo del Imperio Otomano”, Historia Universal siglo XXI, vol. 14, Madrid, 1984.
Caspar, R., Cours de Mystique Musulmane, Institut pontificial d'Etudes Arabes, Roma, 1979.

Chador, M., Sufismo, cultura de la tolerancia, Madrid, 1999.

Chevalier, El sufismo y la tradición islámica, Barcelona, Ed. Kairós, 1974.

Cuadra, M. T., Ibn Arabi, español universal, Madrid, Publicaciones Encuentro, Emilio Galindo, 1977.

Cuadra, C., Graña, M. M., Muñoz, A. y Segura, C., “Saber femenino, saberes de mujeres", en Las sabias mujeres II (siglos II-XVI). Homenaje a Lola Luna, Madrid, AlMudayna, 1995.

El Bokhari, L'authentique tradition musulmane. Choix de h'adiths, (traduction par G. H. Bousquet), Fasquelle Éditeurs, Paris, 1964.

El Corán, Edic. Julio Cortés, Editora Nacional, Madrid, 1980.

Flaquer, J., "El Islam: descripción actual, dimensión mundial; movimientos islámicos", en Eguzkilore, núm. 18, San Sebastián, diciembre, 2004, p. 119-134.

Ghazali, Le livre des bons usages en matière de mariage, París, Adrien Maisonneuve, 1989.

Haddad, L., "Islam, mujer y apuestas del imaginario identitario", Revista CIDOB D'afers Internationals 73-74, pp. 59-68.

Hakîm, S., "Santidad y feminidad en la vida y obra de Ibn Arabi”, en Mujeres de Luz. La mística femenina, lo femenino en la mística, Centro Internacional de Estudios Místicos, Editorial Trotta, Madrid, 2001.

Ibn Arabi, Los sufíes de Andalucía, Editorial Sirio, Málaga, 2007.

Iribas, A., "Psicodelia y Mística", en Mujeres de Luz. La mística femenina, lo femenino en la mística, Centro Internacional de Estudios Místicos, Madrid, Editorial Trotta, 2001.

Lings, M., ¿Qué es el sufismo?, Madrid, Taurus, 1981.

López Pita, P., "Mujeres musulmanas situadas en torno al poder", en Espacio, tiempo y forma, Serie III, Historia Medieval, t. 15, 2002, pp. 95-111.

Luna, A. de, El libro de las claras y virtuosas mujeres, Valladolid, Edic. Manuel del Castillo, Maxtor, 2002.

Martín, J. L., “Historia de España,” 3, Alta Edad Media, Madrid, 1980.

Massignon, L., Essaie sur les origines du lexique technique de la Mystique musulmane, VRIN, Paris, 1985.

Mernissi, F., El poder olvidado, Icaria, Barcelona.

----, Las sultanas olvidadas, Barcelona, Quinteto, 2004

Murata, S., "La luz de la mujer: el principio femenino en el sufismo", en Mujeres de Luz. La mística femenina, lo femenino en la mística, Centro Internacional de Estudios Místicos, Madrid, Editorial Trotta, 2001. 
Nasr, S. H., Vida y pensamiento en el Islam, Herder, 1985.

Nicholson, R. A., Poetas y místicos del Islam, Madrid, Barath, 1986.

Nurbakhsh, J., Mujeres sufies, Ediciones Nur, Madrid, 1999.

Pareja, J. A., Historia de la espiritualidad musulmana, Juan Flors, Barcelona, 1969.

Râbe'Ah Al-'Adawiyya, Dichos y Canciones de una mística Sufí (siglo VIII), edición y traducción de María

Tabuyo Ortega, José J. de Olañeta Editor, Palma de Mallorca, 2006

Rivera Garretas, M. ㄹ M., Textos y espacios de mujeres. Europa SS. IV-XV, Icaria, Barcelona, 1990.

Sachiko, M., "La luz de la mujer: el principio femenino en el sufismo", en Mujeres de Luz. La mística femenina, lo femenino en la mística, Centro Internacional de Estudios Místicos, Editorial Trotta, Madrid, 2001.

Schuon, F., Comprendre l'Islam, París, Editions du Seuil, 1976.

Tabuyo Ortega, M. (ed.), Dichos y Canciones de una mística Sufí (siglo VIII), Palma de Mallorca, José J. de Olañeta Editor, 2006.

Tirmidhi, H. de y Zafrulla Kahn, M., Gardens of the righteous, Londres, Curzon Press, 1989.

Torres Calzada, Katjia, Disquisiciones sobre el velo Islámico, Arcibel Editores, Sevilla, 2008. 